\title{
Pharmaceutico-Analytical study of \\ Naga Bhasma (Incinerated lead) Prepared by Two Different Methods
}

\author{
Research Article
}

\section{Rahul Yashavanth ${ }^{1^{*}}$, Prabhakar U Renjal ${ }^{2}$, Sujatha $\mathbf{K}^{3}$}

1. Technical advisor, Alva Pharmacy, Moodabidri,

2. Professor and HOD, Dept of Rasashastra and Bhaishajya kalpana, SDM College of Ayurveda, Udupi,

3. Professor and HOD, Dept of Rasashastra and Bhaishajya kalpana, SDM College of Ayurveda, Bengaluru.

\begin{abstract}
Naga bhasma (Incinerated Lead) even though having potent qualities is rarely used by the physicians as a medicine due to the fear of toxicity. Marana is a procedure which is followed after the Shodana (cleansing) to remove the ill effects caused by the Naga (Lead) and to make it easily absorbable and assimilable in the body. As various methods are adopted in the preparation, it is difficult to know if the Naga Bhasma prepared by different methods is identical or not. In the current era analysis with the help of current technology is mandatory to study the difference in the properties of Naga Bhasma, hence the present work is being undertaken. Naga necessary for the study was procured from Bangalore and Udupi and Hyderabad. Preparation of Naga Bhasma was done as explained in Rasa Ratna Samucchaya by Jarana (roasting) method (Sample 1) and Ayurveda Prakasha by Puta (enclosed heating) method (Sample 2). In the Analytical study, various parameters such as Bhasma Pariksha, Organoleptic Characters, Physical Constants, Quantitative and Qualitative Analysis were measured. The Naga Bhasma prepared by Puta method was more convenient and cost effective based on the labour work, number of drugs used and the $\mathrm{pH}$ of the sample.
\end{abstract}

Keywords: Naga, Naga Bhasma, Shodana, Marana, Jarana, Puta.

\section{Introduction}

Word 'Dhatu' indicates anything that supports and forms building component of a standing structure. The Dhatu (metals) form a big group of inorganic elements which are available in nature in various forms and in combination with undesired other elements which are not suitable for consumption by humans. The modification and development in Rasashastra are for the purpose of making these elements easily acceptable by the body and to provide maximum therapeutic benefits. This can be achieved through standard classical procedures like Shodana (cleansing) and Marana (Incineration).

Pooti Lohas are one among the various categories of Dhatu. The word Pooti Loha indicates the bad smell which is perceived while heating and melting.

Naga (Lead) is one among the Pooti Loha. In this study Naga with acceptable qualities was taken and subjected to Shodana and Marana procedures and the physicochemical analysis of Naga and Naga Bhasma was carried out in recognized laboratories. The purpose of this study is aimed at preparing two genuine samples of Naga Bhasma as per Rasa Ratna Samucchaya (Sample 1) and Ayurveda Prakasha (Sample 2), to find

*Corresponding Author:

\section{Rahul Yashavanth}

Technical advisor,

Alva Pharmacy,

Moodabidri.

E-mail ID: rahulyashavanth@gmail.com out the most convenient and economical methods of preparation, comparing the two samples and establishing the standard values through analytical studies such as Organoleptic characters, Physical Constants such as Ash value, Total ash, Water soluble ash, Moisture content, $\mathrm{pH}$, Quantitative analysis such as Volumetric/ Gravimetric analysis, Particle size assessment, $\mathrm{pH}$ value, Crystallography by X-Ray Diffraction, Namburi Phased Spot Test.

\section{Materials and Methods \\ Pharmaceutical study \\ Materials}

Grahya Naga procured from Bangalore was taken for the study as it fulfilled the grahya lakshnas and contained $96.27 \%$ of Lead in it.

\section{Methods}

Samanya Shodana of Naga will be carried out as per Rasa Ratna samucchaya.

Naga Bhasma Sample 1-Visesha shodana of Naga and preparation of Naga Bhasma will be carried out as per Rasa Ratna samucchaya.

Naga Bhasma Sample 2 - Visesha shodana of Naga will be carried out as per Rasa Tarangini and preparation of Naga Bhasma will be carried out as per Ayurveda Prakasha.

\section{Experiment 1 \\ Samanya Shodana of Naga (1) \\ Materials}

- Ashoditha Naga (Impure lead) - $2 \mathrm{~kg}$ 
- Tila taila (Sesame oil) - 10.5 litres

- Takra (Buttermilk)- 10.5 litres

- Gomutra (Cow's urine)- 10.5 litres

- Aranala (Sour gruel) - 10.5 litres

- Kulattha kwatha (Horse gram decoction) - 10.5 litres

\section{Apparatus}

Iron vessels, spoon, kosthi (fire place), Peethara yantra, Pyrometer.

\section{Procedure}

A clean iron vessel was taken and ashoditha Naga (impure lead) was placed in it and was heated till the whole Naga melted and converted into liquid state. Later the molten Naga was poured through Peethara Yantra into tila taila. The same procedure was repeated for totally 7 times with fresh media being taken each time. At the end of the repetition for 7 times, Naga was washed with hot water dried and weighed. The same procedure was repeated in takra, gomutra, aranala and kulattha kwatha.

Table 1: Observations in Naga during the Samanya Shodana

\begin{tabular}{|c|c|c|c|c|c|c|}
\hline \multirow[t]{2}{*}{ Media } & \multirow{2}{*}{$\begin{array}{l}\text { Quantity } \\
\text { (before } \\
\text { Shodana) }\end{array}$} & \multirow{2}{*}{$\begin{array}{l}\text { Quantity } \\
\text { (after } \\
\text { Shodana) }\end{array}$} & \multicolumn{2}{|c|}{ Loss / gain } & \multicolumn{2}{|c|}{ Colour Changes } \\
\hline & & & In grams & In \% & Initial & Final \\
\hline Tila taila & 2000 & 2015 & 15 (gain) & $0.75 \%$ & Grey & Dull silver \\
\hline Takra & 2015 & 1990 & $25(\operatorname{loss})$ & $1.24 \%$ & Dull silver & Dull silver \\
\hline Gomutra & 1990 & 1700 & $290(\operatorname{loss})$ & $14.57 \%$ & Dull silver & Bright silver \\
\hline Aranala & 1700 & 1600 & $100(\operatorname{loss})$ & $5.88 \%$ & Bright silver & Bright silver \\
\hline Kulatha kwatha & 1600 & 1450 & $150(\operatorname{loss})$ & $9.37 \%$ & Bright silver & Bright silver \\
\hline
\end{tabular}

Table 2: Changes in the media during Samanya Shodana

\begin{tabular}{|c|c|c|c|c|}
\hline \multirow{2}{*}{ Media } & \multirow{2}{*}{ Initial colour } & \multirow{2}{*}{ Final colour } & \multicolumn{2}{|l|}{ pH } \\
\hline & & & Initial & Final \\
\hline Tila taila & Light brown & Dark brown & & - \\
\hline Takra & White & Dull white & 4.09 & 4.13 \\
\hline Gomutra & Yellow & Mud colour & 7.93 & 9.14 \\
\hline Aranala & White & Dull white & 3.48 & 5.30 \\
\hline Kulatha kwatha & Brown & Brown & 6.92 & 6.66 \\
\hline
\end{tabular}

\section{Results}

Initial quantity -2000 grams

Final quantity obtained - 1450 grams

Loss of weight $-550 \mathrm{gms}(27.5 \%)$

\section{Experiment 2}

Visesha Shodana of Naga as per Rasa Ratna

Samucchaya. (2)

\section{Materials}

- Samanya shoditha Naga (purified Lead) - 550 grams

- Nirgundi mula churna (Powder of root of Vitex negundo Linn.) - 32 grams

- Renuka churna (Powder of seeds of Vitex negundo Linn.)- 32 grams

- Haridra churna (Curcuma longa Linn. powder) - 32 grams

- Nirgundi patra swarasa (Juice of Vitex negundo Linn. leaves) - 2 litres

\section{Apparatus}

Gas stove, iron vessel, Peethara yantra, spoon.

\section{Procedure}

Fine powders of Nirgundi mula, Renuka and Haridra were added to Nirgundi patra Swarasa, stirred well and kept aside. Iron vessel was taken and Naga was placed in it and heated. When Naga melted completely it was carefully poured through peethara yantra containing Nirgundi swarasa. This process was repeated for 3 times. At the end of the procedure, Naga was washed with hot water, dried and weighed.

\section{Observations}

- Naga started to melt at $325^{\circ} \mathrm{C}$.

- A layer of scum was formed above the molten Naga which was removed.

- The colour of the visesha shoditha Naga was bright silver.

\section{Results}

- Initial Quantity -550 grams

- Final quantity obtained - 500 grams

- Loss of weight - 50 grams (9.09\%).

Experiment 3

Naga Marana as per Rasa Ratna Samucchaya Sample 1 (3)

Materials

- Visesha Shoditha Naga (Pure Lead) - 500 grams

- Shuddha Parada ( Purified Mercury) - 7 grams

- Arjuna kshara (ash of stem bark of Terminalia arjuna Roxb.) - 25 grams

- Vibhitaki kshara (ash of fruit of Terminalia bellerica (Gaertn.) Roxb.) - 25 grams

- Aragwadha kshara (ash of stem bark of Cassia fistula Linn.) - 25 grams

- Dadhima kshara (ash of outer covering of fruit of Punica granatum Linn.) - 25 grams 
- Apamarga kshara (ash of whole plant of Achyranthes aspera Linn.) - 25 grams

\section{Apparatus}

Gas stove, iron vessel, spoon, khalwa yantra (Mortar and pestle), pyrometer, cloth.

\section{Procedure}

An amalgam of Naga and Parada (Purified Mercury) was prepared by grinding Molten Parada and Molten Naga together in Khalwa Yantra (mortar and pestle). This mixture of Naga and Parada was taken in a pan and heated. As the amalgam melted, Arjuna kshara was added to it and stirred continuously till the whole mixture got converted into powder. Later the stirring was done frequently and Vibhitaki, Aragwadha, Dadhima and Apamarga kshara were added to the mixture one after the other with the time interval of four days respectively and the heating was carried out for 21 days. The temperature during heating process was maintained in between $600-700^{\circ} \mathrm{C}$.

\section{Observation}

Total time duration taken for the Marana (Incineration) of the Naga was 21 days (480 hours).

Table 3: Observation in Naga Marana (Sample 1)

\begin{tabular}{|l|l|}
\hline $\begin{array}{l}\text { No. of } \\
\text { days }\end{array}$ & \multicolumn{1}{|c|}{ Observation } \\
\hline Day 1 & $\begin{array}{l}\text { Molten Naga + Arjuna kshara continuous } \\
\text { stirring. Fine droplets of molten Naga. After } \\
\text { continuous stirring for 5 hours bright yellow } \\
\text { coloured powder was formed. }\end{array}$ \\
\hline Day 5 & $\begin{array}{l}\text { Vibhitaki kshara was added and stirring was } \\
\text { done for around 30 minutes. The colour of the } \\
\text { powder resembled ash with a dull yellowish } \\
\text { tinge. }\end{array}$ \\
\hline Day 9 & $\begin{array}{l}\text { Aragwadha kshara was added and stirring was } \\
\text { done for around 30 minutes. The colour of the } \\
\text { powder changed to grey with reddish tinge. }\end{array}$ \\
\hline $\begin{array}{l}\text { Day } \\
13\end{array}$ & $\begin{array}{l}\text { Dadhima kshara was added to it and stirred for } \\
\text { around 30 minutes. The colour of the powder } \\
\text { resembled ash with reddish tinge. }\end{array}$ \\
\hline $\begin{array}{l}\text { Day } \\
17\end{array}$ & $\begin{array}{l}\text { Apamarga kshara was added to it and stirred } \\
\text { for around 30 minutes. The colour of the } \\
\text { bhasma resembled ash with reddish tinge. }\end{array}$ \\
\hline $\begin{array}{l}\text { Day } \\
21\end{array}$ & $\begin{array}{l}\text { The colour of the bhasma was red and heating } \\
\text { was stopped. }\end{array}$ \\
\hline
\end{tabular}

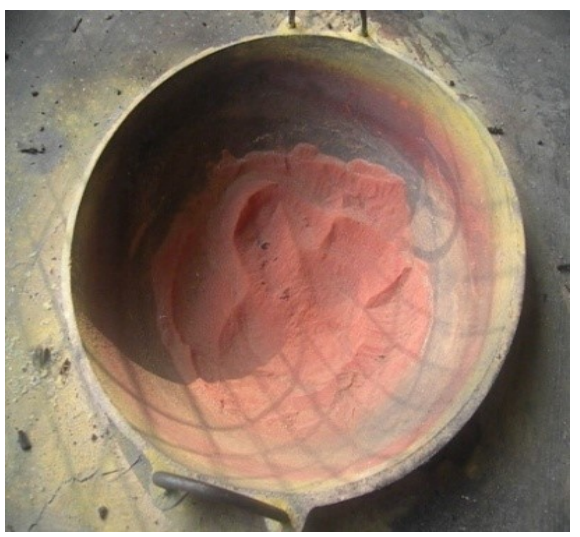

Figure 1: Naga Bhasma (Sample 1)

\section{Results}

- Initial quantity - 500 grams (Naga)

- Final Quantity obtained - 240 grams

- Loss of weight - 260 grams (52\%)

\section{Experiment 4}

Visesha Shodana of Naga as per Rasa Tarangini. (4) Materials

- Samanya shoditha Naga (Purified lead) - 130 grams

- Churnodaka (limewater) - 6 litres

\section{Apparatus}

Gas stove, iron ladle, vessels, peethara yantra, pyrometer.

\section{Procedure}

Samanya Shoditha Naga was taken and melted in an iron ladle. After melting it was poured through peethara yantra into the vessel containing Churnodaka (Lime water). This procedure was repeated for 7 times with each time fresh Churnodaka being taken.

\section{Observation}

- Naga melted at $325^{\circ} \mathrm{C}$.

- A layer of scum was formed during the melting.

- No bad smell was perceived during melting.

- Initial pH of the Churnodaka was 10.43 and after Dhalana the $\mathrm{pH}$ was 8.93 .

\section{Result}

- Initial quantity - 130 grams

- Final quantity obtained - 100 grams

- Loss - 30 grams (23.07\%)

\section{Experiment 5}

Naga Marana as per Ayurveda Prakasha - Sample 2 (5)

\section{Materials required}

- Visesha Shoditha Naga - 100 grams

- Shuddha Manashila (Purified realgar) - 100 grams

- Tambula patra swarasa (Juice of Piper betle Linn.) $850 \mathrm{ml}$

\section{Apparatus required}

Iron ladle, hammer, sharava, cora cloth, multani mitti gas stove, cowdung cakes, pyrometer.

\section{Procedure}

Visesha shoditha Naga was taken and heated. After melting it was soon poured into khalwa yantra and it was hammered to obtain thin sheet. The process was repeated till all the Naga was converted into thin sheets. The paste of shuddha manashila (Purified realgar) triturated with tambula patra swarasa (Juice of Piper betle Linn.) was then applied over Naga sheets and was allowed to dry under sunlight. After drying the sheets were enclosed in sharava samputa (sealed mud saucers).

Next day after drying, the sharava samputa was subjected to puta with 50 cow dung cakes. The tempearature was recorded using a pyrometer and the sharava was collected only after self-cooling. The contents were collected and weighed. The temperature 
recorded during the $1^{\text {st }}$ puta exceeded the melting point of Naga and hence 30 cow dung cakes were used for the next puta and the temperature was recorded and noted. From the $2^{\text {nd }}$ puta onwards Manashila was added in equal quantity to that of Naga Bhasma and was given bhavana with tambula patra swarasa and later chakrikas
(Pellets) were prepared and dried. The weight of the chakrikas were noted and subjected to puta. Next day after self-cooling chakrikas were collected. This process was repeated till Bhasma Siddhi Lakshanas were obtained.

Table No. 4: Observations during the Naga Marana (Sample 2)

\begin{tabular}{|c|c|c|c|c|c|}
\hline $\begin{array}{c}\text { No. Of } \\
\text { Puta }\end{array}$ & $\begin{array}{c}\text { Weight After Each } \\
\text { Puta (grams). Ini- } \\
\text { tial weight of Naga } \\
\mathbf{1 0 0} \text { grams }\end{array}$ & $\begin{array}{c}\text { Gain } \\
\text { in\% }\end{array}$ & Loss in \% & $\begin{array}{c}\text { Peak Tempera- } \\
\text { ture (celsius) }\end{array}$ & $\begin{array}{c}\text { Weight of the Cow dung cakes } \\
\text { (kg) }\end{array}$ \\
\hline 1 & 123 grams & 23 & - & 512 & $5 \mathrm{~kg}$ \\
\hline 2 & 121 grams & - & 1.6 & 248 & $3.1 \mathrm{~kg}$ \\
\hline 3 & 118 grams & - & 2.47 & 252 & $3.1 \mathrm{~kg}$ \\
\hline 4 & 116 grams & - & 1.6 & 254 & $3.1 \mathrm{~kg}$ \\
\hline 5 & 112 grams & - & 3.4 & 249 & $3.1 \mathrm{~kg}$ \\
\hline 6 & 110 grams & - & 1.7 & 250 & $3.1 \mathrm{~kg}$ \\
\hline 7 & 107 grams & & 2.7 & 250 & $3.1 \mathrm{~kg}$ \\
\hline
\end{tabular}

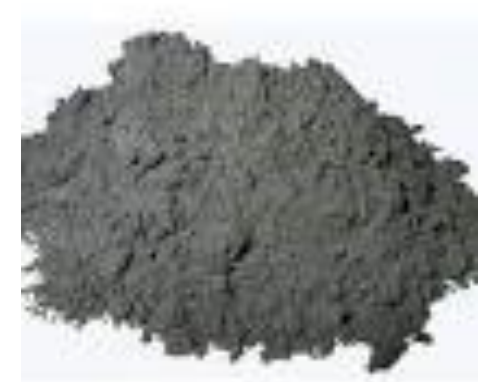

Figure 2: Naga Bhasma (Sample 2)

\section{Results}

- Initial Quantity - 100 grams.

- Final quantity obtained - 107 grams.

- Gain - 7grams (7\%).

\section{Analytical study \\ Materials}

Naga collected from 3 places and 2 samples of Naga Bhasma were subjected to analytical studies at SDM Centre for research and allied science - Udupi, Bangalore Test House -Bangalore and National Institute of Technology - Surathkal and MIT, Maipal.

- 3 Samples of Naga were collected from Bangalore, Hyderabad and Udupi.

- 2 samples of Naga Bhasma are as follows

- Sample I - Prepared according to Rasa Ratna Samucchaya.

- Sample II - Prepared according to Ayurveda Prakasha.

\section{Methods} analysis.

The above samples were subjected to following

- Bhasmapariksha as told in the classics.

- Organoleptic characters.

- Physical constants such as - loss on drying, total ash, acid insoluble ash, water soluble ash and $\mathrm{pH}$ determination.

- Quantitative analysis by titration method.

- Crystallography by X-Ray Diffraction.

- Namboori Phased Spot test.

- Particle size assessment and elemental analysis by SEM -EDAX.

\section{Bhasma Pariksha}

Bhasma pariksha was carried out in the practical hall of Dept. of Rasashastra \& Bhaishajya kalpana, SDMCA, Udupi.

- Varitara- Pinch of sample 1 \& 2 of Naga Bhasma were taken in between the index and the thumb finger, pressed and were gently placed over the stagnant surface of water. Both the sample were found to be floating on the surface of the water. (6)

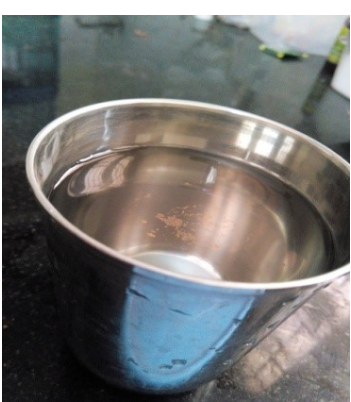

Figure 3: Varitara test Figure 4: Varitara test (Sample 1)

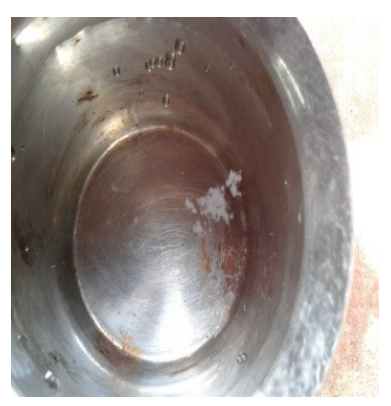

(Sample 2)
- Unama - A rice grain was placed over the floating bhasma, which also floated indicating Unama as positive for both the samples. (7)

- Rekhapurna - Pinch of sample 1 \& 2 of Naga bahsma was taken in between the thumb and the index finger and was rubbed between the two fingers. The bhasma got embedded in the creases of the finger indicating Rekhapurnatva as positive for 
both the samples. (8)

- Nischandratva - Pinch of sample of Naga bhasma was taken and observed under direct sunlight for the presence of metallic lusture. Both the samples passed this test as there was no lusture. (9)

- Avami - Pinch of sample $1 \& 2$ of Naga bhasma was taken and placed on the tongue. No nausea and vomiting were seen in both the samples indicating Avami as positive for both the samples.(10)

- Nisvadu - Pinch of sample 1 \& 2 of Naga bhasma was taken and placed on the tongue individually. No taste was perceived indicating Nisvadu as positive for both the samples. (11)

- Dantagrekachakacha - Pinch of sample $1 \& 2$ of Naga bhasma was taken and placed in between the teeth and grinded. There was no harsh sensation indicating the test as positive for both the samples. (12)

- Niruttha - Equal quantity of sample 1 \& 2 of Naga Bhasma and silver were taken and placed in different crucible and heated to $450^{\circ} \mathrm{C}$ for 1 hour. After selfcooling the silver was collected and the weight was noted. No increase in the weight of the silver was found, indicating Niruttha as positive for both the samples. (13)

- Apunarbhava - 2 grams of sample $1 \& 2$ of Naga Bhasma each were taken separately along with equal quantites of gunja (Abrus precatorius Linn.), guda (jaggery), tankana (Purified borax), madhu (honey) and ghrita (ghee) were taken and grinded. Chakrikas of both the samples of Naga Bhasma were prepared and dried and later was subjected to puta at $450^{\circ} \mathrm{C}$. No metallic particles were seen after heating indicating Apunarbhava as positive for both the samples. (14)

\section{Organoleptic characters}

Organoleptic characters of ashodita naga and both the samples of Naga Bhasma was carried out in the practical hall of Dept. of Rasashastra \& Bhaishajya kalpana, SDMCA, Udupi.

Table 5: Organoleptic characters of Ashodita Naga

\begin{tabular}{|c|c|}
\hline Parameter & Sample 1 \\
\hline Appearance & Solid Mass \\
\hline Colour & Dull Silver \\
\hline Taste & Tasteless \\
\hline Touch & Smooth \\
\hline Odour & Odourless \\
\hline
\end{tabular}

Table 6: Organoleptic characters of Naga Bhasma

\begin{tabular}{|c|c|c|}
\hline Parameter & Sample 1 & Sample 2 \\
\hline Appearance & Powder & Powder \\
\hline Colour & Red & Dull black \\
\hline Taste & Tasteless & Tasteless \\
\hline Touch & Smooth & Smooth \\
\hline Odour & Odourless & Odourless \\
\hline
\end{tabular}

Physico - chemical analysis of Naga Bhasma was carried out at SDM Centre for research and allied science - Udupi.

Table 7: Physico - Chemical analysis of Naga Bhasma

\begin{tabular}{|c|c|c|}
\hline Parameter & $\begin{array}{c}\text { Naga Bhasma } \\
\text { Sample 1 }\end{array}$ & $\begin{array}{c}\text { Naga Bhasma } \\
\text { Sample 2 }\end{array}$ \\
\hline Loss on drying & $0.46 \%$ & $0.1 \%$ \\
\hline Total Ash & $96.27 \%$ & $100 \%$ \\
\hline $\begin{array}{c}\text { Acid Insoluble } \\
\text { Ash }\end{array}$ & $23.21 \%$ & $75.09 \%$ \\
\hline $\begin{array}{c}\text { Water Soluble } \\
\text { Ash }\end{array}$ & $11.28 \%$ & $0 \%$ \\
\hline pH & 9.8 & 6.27 \\
\hline
\end{tabular}

Percentage of Lead in Naga Bhasma (Sample 1 \& 2) respectively was analysed at Bangalore Test House, Bangalore.

Table 8: Percentage of Lead in Naga Bhasma Titration Method

\begin{tabular}{|c|c|}
\hline Sample & \% of Lead \\
\hline Sample 1 & 37.93 \\
\hline Sample 2 & 70.81 \\
\hline
\end{tabular}

\section{X - Ray Diffraction (X-RD)}

X- Ray Diffraction of Naga Bhasma (Sample 1 \& 2) respectively was carried out at MIT, Manipal. Instrument used $-\mathrm{X}$ ray diffractometer.

\section{Sample Preparation}

About 1 gram of fine powder of both the samples of Naga Bhasma was placed in the sample holder of the $\mathrm{X}$-Ray diffractometer. Surface of the sample was made flat to avoid any error out of the rough surface specimen. The $\mathrm{X}$ - ray diffractograms were taken in a $\mathrm{X}$ -Ray diffractometer with a target at $25 \mathrm{KV}$ and 10MA.

The reports of the X-RD showing the peak height intensity are shown below.

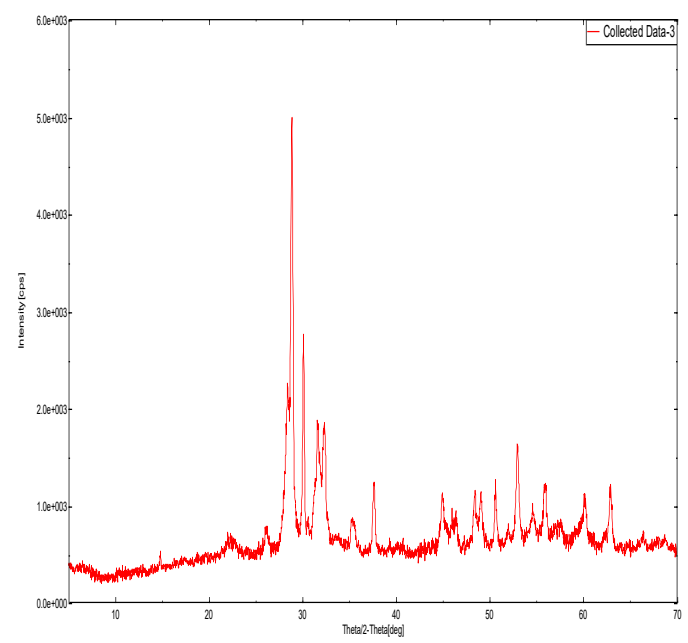

Figure 5: Naga Bhasma Sample 1 


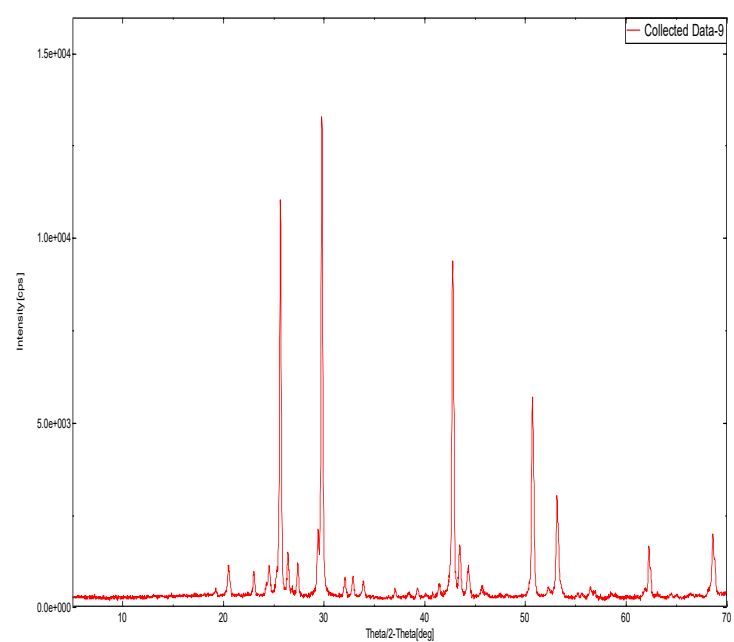

Figure 6: Naga Bhasma - Sample 2

The above 2 graphs indicate the crystalline nature of both the samples of Naga Bhasma.

\section{Namburi Phased Spot Test (NPST)}

NPST of Naga Bhasma (Sample 1 \& 2) respectively was carried out in the practical hall of Dept. of Rasashastra \& Bhaishajya kalpana, SDMCA, Udupi.

\section{Apparatus}

Petri dish, $0.5 \mathrm{ml}$ pipette, Digital Balance, Test tubes, Whatman Paper No. 1.

\section{Procedure}

Two Whatman filter paper No. 1 were taken and were soaked in a petri dish containing $10 \%$ Potassium iodide Solution, removed and later allowed to dry. 0.25 grams of both the samples of Naga Bhasma were taken in a test tube and to this $0.5 \mathrm{ml}$ of $5 \mathrm{~N} \mathrm{HNO}_{3}$ was added and heated for a period of about 1 minute. The contents were later allowed to react for a period of 72 hours by shaking the test tube every now and then. After 72 hours the supernatant fluid was taken and was dropped with the help of a dropper at the centre of $10 \%$ potassium iodide paper. Observations were done up to 5 minutes (I phase), 20 minutes (II Phase) and 24 hours (III Phase).

\section{Sample 1}

$1^{\text {st }}$ phase - A solid yellow spot was formed which turned immediately into deep yellow central solid spot with a light red spot surrounding the yellow spot.

$2^{\text {nd }}$ phase - It continued to be the same in the $2^{\text {nd }}$ phase.

$3^{\text {rd }}$ phase - The yellow colour around the central spot faded partially.

\section{Sample 2}

$1^{\text {st }}$ phase - A solid yellow spot was formed which turned immediately into deep yellow central solid spot with a dark red spot surrounding the yellow spot.

$2^{\text {nd }}$ phase - The red colour around the yellow spot was darker and started to spread. $3^{\text {rd }}$ phase - The yellow colour around the central spot faded partially and the red spot surrounding the yellow spot was seen spreading further.

\section{Dissimilarities in the NPST of the two samples.}

- The central yellow spot in sample 2 was less bright than that of sample 1 .

- The red spot surrounding the yellow spot in the sample 1 was light when compared to that of sample 2.

- The red spot did not spread further in sample 1 whereas in sample 2 it spread further.

NPST of Naga Bhasma Sample 1

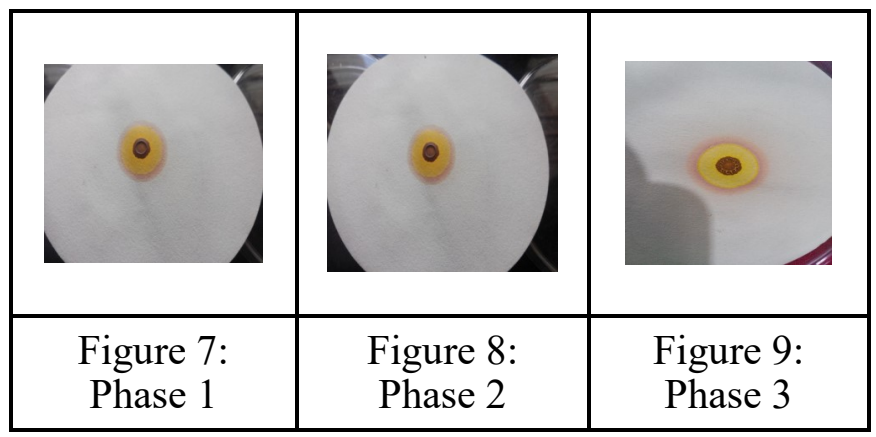

NPST of Naga Bhasma Sample 2

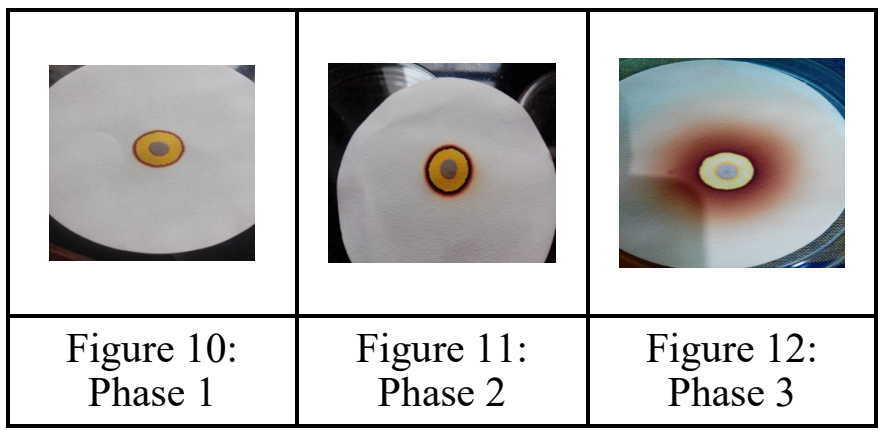

\section{Atomic Absorption Spectroscopy (AAS)}

Percentage of Iron and Arsenic in Naga Bhasma by Atomic absorption Spectroscopy was carried out at Bangalore test house, Bangalore.

Instrument used - AAS spectrometer.

\section{Apparatus}

NitricAcid, Hydrogen Peroxide, Microwave Digester, AAS Spectrometer, Volumetric flasks.

\section{Procedure}

0.5 grams of the samples of Naga Bhasma were taken in different digestion vessels. $8 \mathrm{ml}$ of Nitric Acid and $2 \mathrm{ml}$ of Hydrogen Peroxide were added to individual vessels and kept for 30 minutes and were digested at $150^{\circ} \mathrm{C}$ for about 15 minutes. After digestion the volume was made upto $50 \mathrm{ml}$ with MilliQ water. Blank and various concentrations of standard were prepared. Calibaration curve was plotted using appropriate standards. Bhasma samples were analyzed and the results were calculated according to the weight of the samples taken for digestion. 
Table 9: Percentage of Iron and Arsenic determined in Naga bhasma by AAS

\begin{tabular}{|c|c|c|}
\hline Sample & Iron in \% & Arsenic in \% \\
\hline Sample 1 & $\mathbf{6 . 2 8 \%}$ & - \\
\hline Sample 2 & - & $\mathbf{2 . 1 8 \%}$ \\
\hline
\end{tabular}

Elemental analysis of Ashodita Naga and Naga Bhasma and particle size assessment of Naga Bhasma

Elemental analysis of ashodhita naga, Naga Bhasma (Sample $1 \&$ 2) and particle size estimation of Naga Bhasma (Sample $1 \&$ 2) was carried out at NITK, Surathkal.

Instrument used - Scanning Electron Microscope - Energy dispersive x-ray analyser (SEM - EDAX).

Elemental analysis of ashodhita naga and two samples of Naga Bhasma was done using Energy dispersive $\mathrm{x}$-ray analyser whereas the particle size assessment of both the samples of Naga Bhasma was done using scanning electron microscope.

\section{Sample preparation}

Three samples of ashoditha Naga of an appropriate size and two samples of Naga Bhasma were taken so as to fit in the specimen chamber and were generally mounted rigidly on a specimen holder called the specimen stub and scanned under the microscope.

\section{Table 10: Elemental Analysis of Ashodhita Naga (Impure Lead)}

\begin{tabular}{|l|l|l|l|}
\hline $\begin{array}{l}\text { Elements } \\
\text { (Mass \%) }\end{array}$ & Bangalore & Hyderabad & Udupi \\
\hline Lead $(\mathrm{Pb})$ & 97.36 & 59.69 & 69.01 \\
\hline Sulphur (S) & 1.30 & 1.69 & 1.01 \\
\hline Carbon (C) & 18.03 & 22.52 & - \\
\hline Oxygen (O) & 1.34 & 14.63 & 10.47 \\
\hline $\begin{array}{l}\text { Sodium } \\
(\mathrm{Na})\end{array}$ & - & 1.46 & - \\
\hline $\begin{array}{l}\text { Aluminium } \\
(\mathrm{Al})\end{array}$ & - & - & 0.33 \\
\hline Tin $(\mathrm{Sn})$ & - & - & 1.15 \\
\hline
\end{tabular}

Table 11: Elemental Analysis of Naga Bhasma

\begin{tabular}{|l|l|l|}
\hline $\begin{array}{l}\text { Elements } \\
(\text { Mass \%) }\end{array}$ & Sample 1 & Sample 2 \\
\hline Lead $(\mathrm{Pb})$ & 40.26 & 65.14 \\
\hline Iron $(\mathrm{Fe})$ & 7.69 & - \\
\hline Calcium $(\mathrm{Ca})$ & 1.45 & 1.13 \\
\hline Potassium $(\mathrm{K})$ & 7.14 & - \\
\hline Oxygen $(\mathrm{O})$ & 10.89 & 10.58 \\
\hline Chlorine $(\mathrm{Cl})$ & 0.80 & - \\
\hline Tin $(\mathrm{Sn})$ & 1.77 & 8.71 \\
\hline Arsenic $(\mathrm{As})$ & - & 4.96 \\
\hline Zinc $(\mathrm{Zn})$ & - & 2.23 \\
\hline
\end{tabular}

\section{Particle Size Assessment}

\section{Naga Bhasma - Sample 1}

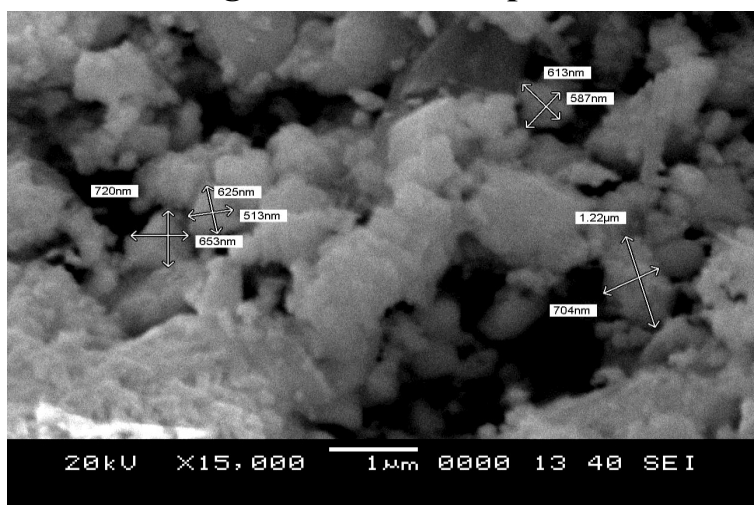

Figure 9: Naga Bhasma Sample 1

Naga Bhasma - Sample 2

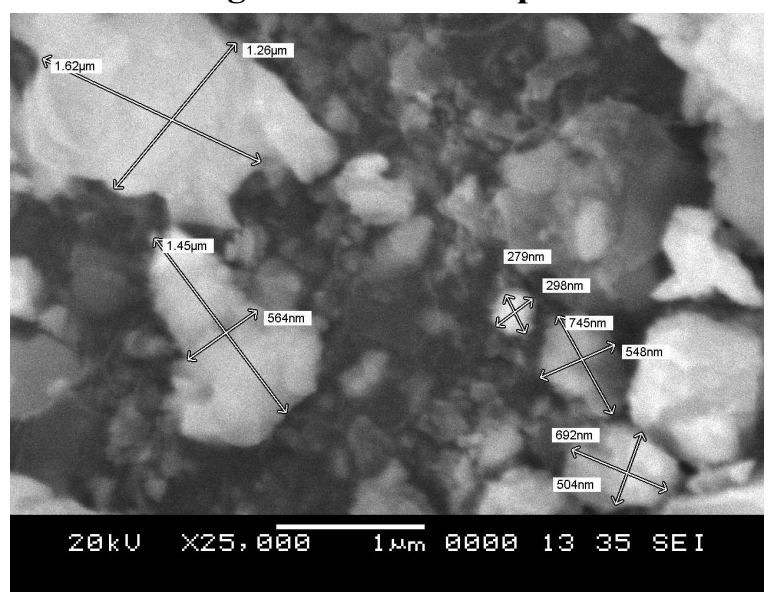

Figure 10: Naga Bhasma Sample 2

\section{Discussion}

In the treatises of Rasashastra, especially earlier books like RasendraMangala, Rasarnava used Naga for the purpose of Dhatuwaada and Dehavada, later from Rasendra Chudamani onwards detailed reference about Shodana, Marana Properties and indications of Naga can be seen. The Word 'PootiLoha' indicates that when it is heated or melted it emits bad smell but practically it is not seen. Probably it may indicate the quick tarnishing to dull greyish colour when exposed to atmosphere by forming a complex mixture of compounds depending on the conditions. The colour of the compounds can vary. The tarnish layer can contain significant amounts of carbonates and hydroxycarbonates or the scum which is formed over the surface of molten Naga when being heated.

In samanya shodhana five liquid media were used out of which 3 liquid media were acidic, 1 was basic and 1 was neutral in nature respectively. The alternate heating and quenching in these acidic and basic liquid media may cause the removal of acid and alkali soluble impurities from the metal. Change in the $\mathrm{pH}$ of takra from 4.09 (acidic) to 4.13, change in the $\mathrm{pH}$ of gomutra from 7.93 to 9.14 and change in the $\mathrm{pH}$ of aranala from 3.48 (acidic) to 5.30 all signifies the removal of alkaline impurities, whereas change in the $\mathrm{pH}$ of kulattha kwatha from 6.92 to 6.66 indicates the removal of acidic impurities. 


\section{Naga Bhasma (Sample 1)}

ViseshaShodana of Naga was done in Nirgundipatra swarasa mixed with Nirgundimula, Haridra and Renuka churna. Shodana was done in Katu Rasa dravya i.e Nirgundi swarasa, which may be effective due to the pharmacological effects of Katu rasa such as agni deepaka, lekhana, sroto vilayana etc. As the definition itself says that Visesha Shodana is done to induce therapeutic property to the drug, hence it may be useful. Marana of Naga was carried out by amalgamation with Parada which helps in dissociation of metal. During heating on the $1^{\text {st }}$ day a bright yellow colour powder was formed which signifies the oxidation process of lead resulting into the formation of Lead Oxide. Gradually when the heating continued the colour changed from yellow to dull red on day 7 and then finally red colour on day 18 . The red colour of the Naga Bhasma signifies further oxidation of Lead Oxide to Tri Lead Tetra Oxide.

\section{Naga Bhasma (Sample 2)}

Visesha shodhana of Naga was done in Churnodaka, the probable reason for selecting churnodaka is, it being alkaline in nature will help in removing the acidic impurities present in the samanya shodhita Naga. For the Marana of Naga, fine sheets of Naga were prepared by continuous hammering which signifies the Malleability property present in the Naga even after the Shodana. 50 cow dung cakes were used for the Puta and it was observed that the maximum temperature reached $512^{\circ} \mathrm{C}$ which was more than the melting point of $\operatorname{Naga}\left(326^{\circ} \mathrm{C}\right)$, due to which some part of the Naga remained in the metallic form. The metallic form was separated from the powder form and was melted, made into thin sheets and was subjected to puta (with the paste of shuddha Manashila applied over it) with 30 cow dung cakes and the maximum temperature recorded was around $252^{\circ} \mathrm{C}$. Within 2 puta the whole of it got converted into powder form. Such 7 puta were required for the preparation of Naga Bhasma.

Table 12: Differences in both the procedures of Marana

\begin{tabular}{|c|l|l|}
\hline $\begin{array}{c}\text { Sl. } \\
\text { No. }\end{array}$ & \multicolumn{1}{|c|}{ Sample 1 } & \multicolumn{1}{c|}{ Sample 2 } \\
\hline 1 & $\begin{array}{l}\text { Method adopted - } \\
\text { Jarana }\end{array}$ & $\begin{array}{l}\text { Method adopted - } \\
\text { puta }\end{array}$ \\
\hline 2 & $\begin{array}{l}\text { Time duration } \\
\text { required for the } \\
\text { procedure }-21 \text { days. }\end{array}$ & $\begin{array}{l}\text { Time duration } \\
\text { required for the } \\
\text { procedure -23 days }\end{array}$ \\
\hline 3 & $\begin{array}{l}\text { Final quantity - 52\% } \\
\text { loss }\end{array}$ & $\begin{array}{l}\text { Final quantity - 7\% } \\
\text { gain }\end{array}$ \\
\hline 4 & Red coloured Bhasma & $\begin{array}{l}\text { Dull black coloured } \\
\text { Bhasma }\end{array}$ \\
\hline
\end{tabular}

\section{Analytical Study}

3 samples of Naga were purchased and analysed for grahya lakshnas. All the samples possessed the grahya lakshanas in it. Further all the samples were subjected to SEM EDAX for the estimation of Lead percentage. The sample procured from Bangalore was found to have the highest percentage of lead in it $(97.36 \%)$ compared to Udupi sample (69.01\%) and Hyderabad (59.69\%), hence Naga procured from Bangalore was used for the study. In the bhasma pariksha, Varitara and Unnama- were positive which indicated Naga Bhasma was so light in weight that it couldn't break the surface tension of water and had specific gravity less than that of water.

- Rekhapurnatva - Indicates the fineness of the Bhasma.

- Nischandratva - Absence of metallic lustre in the Bhasma indicates the absence of the metallic particles.

- Avami and Nisvadu -Both the samples of the Bhasma when placed over the tongue didn't produce any nausea and were tasteless which indicates absence of Naga in the metallic form.

- Dantagre kacha kacha - Indicates the fineness and softness of the particles.

- Niruttha - No gain in the weight of the Silver indicates complete absence of metallic particles.

- Apunarbhava - The Mitra Panchaka reduces the melting point of the drug. When the drug is heated with Mitra Panchaka if the Bhasma contains metallic particles, it will attain its original state. Metal did not regain its original form which indicates the absence of metallic particles.

\section{Modern Analytical Parameters}

The total ash, water soluble ash and acid insoluble ash contents have been widely used as one of the indices to illustrate the quality as well as purity of the medicine. The ash value is related to the inorganic material in the drug. The actual value depends upon the three factors, firstly the inorganic material naturally present in the drug, secondly addition by the processes and thirdly upon possible subsequent contaminations. The total ash method is designed to measure the total amount of materials remaining after the ignition. This includes both physiological ash which is derived from the drug itself and nonphysiological ash which is the residue of the media used during the procedure.

Acid insoluble ash is the residue obtained after boiling the total ash with dilute hydrochloric acid, and igniting the remaining insoluble matter. This measures the amount of silica present as sand. Water soluble ash is the difference in the weight between the total ash and the residue after the treatment of total ash with water.

Naga Bhasma sample 2 is completely inorganic in nature as it contains $100 \%$ ash compared to Naga Bhasma sample 1 wherein it contains $96.27 \%$.

The percentage of acid insoluble ash is more in the Naga bhasma sample 2 i.e. $75.09 \%$ compared to that of sample1 i.e. $23.21 \%$. It could be due to the addition of sand from the sharava and mulatani mitti used for Sandhibandhana. The \% of water soluble ash was nil in sample 2 whereas in sample 1 it was $11.28 \%$. It could be due to the presence of water soluble part in the Kshara added during the procedure. The $\mathrm{pH}$ of the sample 2 is 6.27 which is nearly neutral 
whereas the $\mathrm{pH}$ of the sample 1 is 9.8 which is alkaline. It indicates that the sample 2 with the neutral $\mathrm{pH}$ is fit for therapeutic purpose.

The $\%$ of Lead in impure Lead was $97.36 \%$ whereas in Naga bhasma sample 1 it is $37.93 \%$ which is less than Naga Bhasma sample 2 wherein it is $70.81 \%$. Here the probable reason for the decrease in the quantity of lead in sample 1 could be because of the procedure which was conducted in an open environment that will lead to maximum oxidation.

$\mathrm{X}-\mathrm{RD}$ analysis of both the samples of Bhasma shows that they are crystalline in nature.

Namburi phased spot test is done for the qualitative assessment of the drug wherein a chemical reaction takes place between the sample solution and the chemical paper used because of which a particular colour pattern is formed. NPST of both the samples of Naga Bhasma were nearly equal to the standards as mentioned in the books.

The elemental analysis of Naga Bhasma shows the presence of elements like Lead $(\mathrm{Pb})$, Iron $(\mathrm{Fe})$, Calcium (Ca), Potassium (K), Oxygen (O), Chlorine (Cl), Sulphur (S) in sample 1. The quantity of Iron estimated through AAS and SEM are 6.28\% and $7.69 \%$ respectively. The probable reason for the presence of iron may be due to the preparation of the Bhasma in an iron vessel and some part might have been present in the kshara (ash) of the different drugs which were added during the procedure. Presence of oxygen is due to the oxidation and elements like Calcium $(\mathrm{Ca})$, Potassium $(\mathrm{K})$, Chlorine $(\mathrm{Cl})$ might be from the kshara added during the preparation. The element Sulphur (S) was present in the raw drug. Sample 2 contained elements like Lead $(\mathrm{Pb})$, Calcium (Ca), Oxygen (O), Sulphur (S), Arsenic (As), Zinc (Zn). The quantity of Arsenic estimated through AAS and SEM are $2.18 \%$ and $4.96 \%$. The probable reason for the presence of Arsenic is due to the addition of Manashila during the preparation of Naga Bhasma. Other elements like Calcium (Ca), Zinc (Zn) might have been present in Tambulapatra which was used as a Bhavana dravya (Liquid media for trituration). The element Sulphur (S) was present in the Raw Lead.

The particle size assessment of sample 1 shows particle size ranging from $382 \mathrm{~nm}-1.72$ micro meter whereas the particle size assessment of sample 2 shows particle size ranging from $372 \mathrm{~nm}-1.62$ micro meter. This indicates that the continuation of the procedure may reduce the maximum particles of the Bhasma to nano size.

\section{Conclusion}

Duration required for the Marana of Naga through Jarana method is 21 days and for that of Puta method is 23 days. The colour of Naga Bhasma prepared through Jarana method is red and Puta method is dull black. Naga bhasma prepared by Puta method is completely inorganic in nature as it contains $100 \%$ ash whereas in Jarita method $96.27 \%$ are inorganic materials with traces of organic materials which signify the presence of carbon. The \% of Lead in Naga Bhasma prepared through the Jarana method was 37.93 and in Puta method was 70.81. Naga Bhasma prepared by Jarana method contains trace elements like iron, Calcium, Potassium, Oxygen, Chlorine and Sulphur whereas that prepared by Puta method contains trace elements like Calcium, Oxygen, Sulphur, Arsenic and Zinc. pH of Naga Bhasma prepared by Jarana method was 9.8 and that prepared by Putapaka method was 6.27. Naga Bhasma prepared by Jarana and Puta method are crystalline in nature. Colour pattern obtained by the NPST shows that Naga Bhasma prepared by Jarana and Puta method are standard. Hence to conclude, Naga Bhasma prepared by Puta method was more convenient and cost effective based on the labour work, number of drugs used and the $\mathrm{pH}$ of the sample. Further Studies like toxicity, experimental and clinical studies can be carried out.

\section{Reference}

1. Vagbhata. Rasa Ratna Samucchaya. Reprint edition, New Delhi; Meharchand Lakshmandas Publications; 2007. 93p.

2. Vagbhata. Rasa Ratna Samucchaya. Reprint edition, New Delhi; Meharchand Lakshmandas Publications; 2007. 126p.

3. Vagbhata. Rasa Ratna Samucchaya. Reprint edition, New Delhi; Meharchand Lakshmandas Publications; 2007. 127p.

4. Sharma Sadanand. Rasa Tarangini. Reprint edition, New Delhi; Motilal Banarsidas; 2012. 458p.

5. Sri Madhava. Ayurveda Prakasha. $4^{\text {th }}$ edition. Varanasi; Chwokambha Vishva Bharati ; 1994. 383p.

6. Vagbhata. Rasa Ratna Samucchaya. Reprint edition, New Delhi; Meharchand Lakshmandas Publications; 2007. 212p.

7. Vagbhata. Rasa Ratna Samucchaya. Reprint edition, New Delhi; Meharchand Lakshmandas Publications; 2007. 213p.

8. Sri Madhava. Ayurveda Prakasha. $4^{\text {th }}$ edition. Varanasi; Chwokambha Vishva Bharati ; 1994. 285 p.

9. Sri Madhava. Ayurveda Prakasha. $4^{\text {th }}$ edition. Varanasi; Chwokambha Vishva Bharati ; 1994. 373p.

10. Sri Madhava. Ayurveda Prakasha. $4^{\text {th }}$ edition. Varanasi; Chwokambha Vishva Bharati ; 1994. 285 p.

11. Sri Madhava. Ayurveda Prakasha. $4^{\text {th }}$ edition. Varanasi; Chwokambha Vishva Bharati ; 1994. 285 p.

12. Vagbhata. Rasa Ratna Samucchaya. Reprint edition, New Delhi; Meharchand Lakshmandas Publications; 2007. 213p.

13. Vagbhata. Rasa Ratna Samucchaya. Reprint edition, New Delhi; Meharchand Lakshmandas Publications; 2007. 212p. 